\title{
Carbonate Formation and Decomposition on Atomic Oxygen Precovered $\mathrm{Au}(111)$
}

\author{
Rotimi A. Ojifinni, Jinlong Gong, Nathan S. Froemming, David W. Flaherty, Ming Pan, \\ Graeme Henkelman, and C. Buddie Mullins* \\ University of Texas at Austin, Departments of Chemical Engineering and Chemistry, Center for Nano- and Molecular \\ Science and Technology, and Texas Materials Institute, 1 University Station C0400, Austin, Texas 78712-0231
}

Received May 9, 2008; E-mail: Mullins@che.utexas.edu

The carbonate formation and decomposition $\left(\mathrm{CO}_{3} \leftrightarrow \mathrm{CO}_{2}+\mathrm{O}_{\mathrm{a}}\right)$ reaction on gold is important from the point of view of lowtemperature $\mathrm{CO}$ oxidation. Carbonate formation has been proposed as a possible reaction intermediate in $\mathrm{CO}$ oxidation in several investigations of supported and unsupported gold clusters. ${ }^{1-4}$ Therefore, an understanding of this reaction on $\mathrm{Au}(111)$ may provide additional insight. Carbonate formation and decomposition went undetected in previous studies on $\mathrm{Au}(110)^{5}$ and $\mathrm{Au}(111){ }^{6}$ However, a surface carbonate was readily formed when oxygen precovered $\mathrm{Ag}(110)$ was exposed to $\mathrm{CO}_{2}$ at $300 \mathrm{~K}^{7-10}$ This surface carbonate decomposes to produce $\mathrm{CO}_{2}$ at $485 \mathrm{~K}$ and the remaining oxygen atoms recombinatively desorbed at $590 \mathrm{~K}^{7-10}$ Owing to its similarity with silver, we would anticipate equally facile carbonate formation and decomposition reactions on gold. Similar reactions have also been reported on other surfaces. ${ }^{11-13}$

Here we present experimental evidence with supporting density functional theory (DFT) calculations of carbonate formation and decomposition from the adsorption of oxygen-labeled carbon dioxide $\left(\mathrm{C}^{18} \mathrm{O}_{2}\right)$ on an atomic oxygen $\left({ }^{16} \mathrm{O}\right)$ precovered $\mathrm{Au}(111)$ surface. We studied the effects of $\mathrm{CO}_{2}$ exposure, surface temperature, and oxygen coverage on carbonate formation and decomposition and also estimated reaction probabilities $\left(\sim 10^{-3}-10^{-4}\right)$ and activation energies as a function of conditions.

Our experiments were performed in a UHV chamber that has been described elsewhere, ${ }^{14-19}$ but details specific to this study are briefly summarized here. The $\mathrm{Au}(111)$ single crystal sample is mounted to a tantalum plate that can be resistively heated and is in thermal contact with a liquid nitrogen bath. Oxygen $\left({ }^{16} \mathrm{O}\right)$ atoms were deposited using a radio frequency (RF) plasma-jet source. The ${ }^{16} \mathrm{O}_{\mathrm{a}} / \mathrm{Au}(111)$ surface was exposed to $\mathrm{C}^{18} \mathrm{O}_{2}$ by backfilling the chamber and carbonate ${ }^{16} \mathrm{OC}^{18} \mathrm{O}^{18} \mathrm{O}$ was formed. The surface carbonate decomposes to form either $\mathrm{C}^{18} \mathrm{O}_{2}$ or ${ }^{16} \mathrm{O} \mathrm{C}^{18} \mathrm{O}$ leaving ${ }^{18} \mathrm{O}_{\mathrm{a}}$ or ${ }^{16} \mathrm{O}_{\mathrm{a}}$ adatoms on the surface. Upon heating, the oxygen atoms undergo recombinative desorption to produce ${ }^{16} \mathrm{O}_{2}$ (mass 32) and ${ }^{16} \mathrm{O}^{18} \mathrm{O}$ (mass 34), as observed in TPD. Thus, carbonate formation and decomposition were detected via the increased presence of mass $34{ }^{18} \mathrm{O}^{16} \mathrm{O}$ in a temperature programmed desorption (TPD) spectrum after the ${ }^{16} \mathrm{O}_{\mathrm{a}}$ covered $\mathrm{Au}(111)$ surface was exposed to $\mathrm{C}^{18} \mathrm{O}_{2}$. We did not observe ${ }^{18} \mathrm{O}_{2}$ (mass 36) in TPD due to the very small surface concentration of ${ }^{18} \mathrm{O}$. This method was employed after other strategies proved unsuccessful because of the low reaction probability.

Figure 1a displays TPD spectra of ${ }^{16} \mathrm{O}^{18} \mathrm{O}(m / e=34)$ produced from exposure of the ${ }^{16} \mathrm{O}_{2} / \mathrm{Au}(111)$ surface to $\mathrm{C}^{18} \mathrm{O}_{2}$. The amount of ${ }^{16} \mathrm{O}^{18} \mathrm{O}$ produced increases with $\mathrm{C}^{18} \mathrm{O}_{2}$ exposure at $167 \mathrm{~K}$ (and all temperatures studied). Two control experiments were performed to ascertain the source of ${ }^{16} \mathrm{O}^{18} \mathrm{O}$. First, no mass 34 was produced when the $\mathrm{Au}(111)$ surface was exposed to $\mathrm{C}^{18} \mathrm{O}_{2}$ without preadsorbed atomic oxygen. Second, only $\sim 0.5 \%$ of the total amount
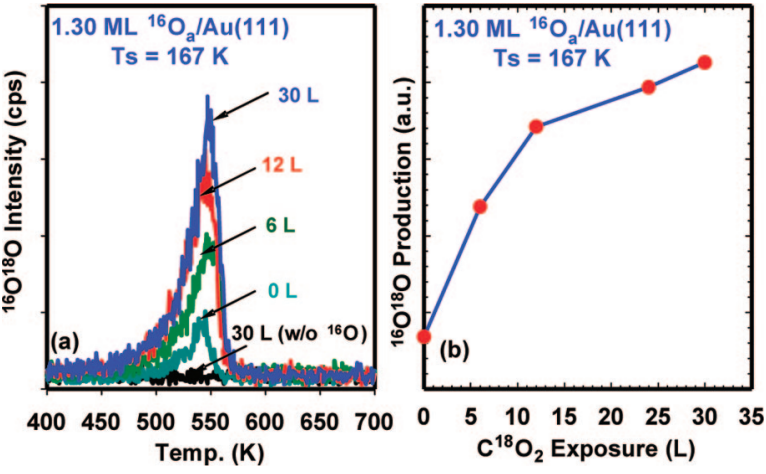

Figure 1. (a) TPD of ${ }^{16} \mathrm{O}^{18} \mathrm{O}(m / e=34)$ after a $\mathrm{Au}(111)$ surface covered with $1.3 \mathrm{ML}{ }^{16} \mathrm{O}$ at $77 \mathrm{~K}$ was exposed to varying amounts $(0-30 \mathrm{~L}$, where $1 \mathrm{~L}=10^{-6}$ Torr $\cdot \mathrm{s}$ ) of $\mathrm{C}^{18} \mathrm{O}_{2}$ at $167 \mathrm{~K}$; (b) ${ }^{16} \mathrm{O}^{18} \mathrm{O}$ production as a function of $\mathrm{C}^{18} \mathrm{O}_{2}$ exposure.

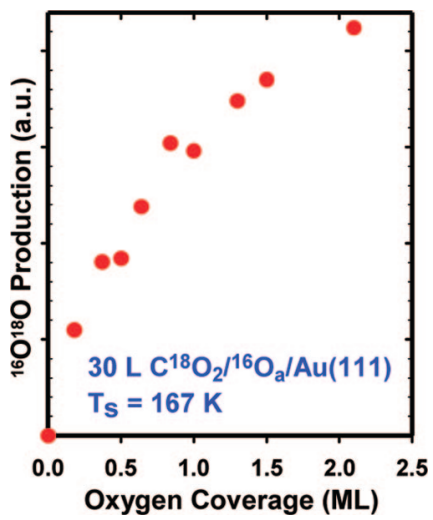

Figure 2. Integrated TPD area of ${ }^{16} \mathrm{O}^{18} \mathrm{O}$ (mass 34) for varying initial oxygen precoverages $(0.18-2.1 \mathrm{ML})$ on which $30 \mathrm{~L}$ of $\mathrm{C}^{18} \mathrm{O}_{2}$ was reacted at $167 \mathrm{~K}$. The contribution to the signal due to the natural abundance of ${ }^{18} \mathrm{O}$ has been subtracted off.

of oxygen desorbs as mass 34 when the $\mathrm{Au}(111)$ surface is precovered with ${ }^{16} \mathrm{O}$ but with no exposure to $\mathrm{C}^{18} \mathrm{O}_{2}$ (due to natural isotopic abundance of ${ }^{18} \mathrm{O}$ ). As expected, no surface-bound oxygen was lost during carbonate formation and decomposition, in agreement with previous studies. ${ }^{8-10}$ Figure $1 \mathrm{~b}$ shows the amount of mass 34 produced (from the spectra in Figure 1a) as a function of $\mathrm{C}^{18} \mathrm{O}_{2}$ exposure.

To further examine the role of preadsorbed atomic oxygen on carbonate formation, we varied the oxygen precoverage $(0.18-2.1$ ML) while keeping both $\mathrm{C}^{18} \mathrm{O}_{2}$ exposure $(30 \mathrm{~L})$ and surface temperature $(167 \mathrm{~K})$ constant (Figure 2). Mass 34 production increases with increasing ${ }^{16} \mathrm{O}_{\mathrm{a}}$ coverage, likely because more reactive oxygen is accessible to $\mathrm{C}^{18} \mathrm{O}_{2}$ on the surface. Similar results were obtained employing surface temperatures of 220 and $300 \mathrm{~K}$. 




Figure 3. Arrhenius plot of $\mathrm{C}^{18} \mathrm{O}_{2}$ reaction probability using a constant $\mathrm{C}^{18} \mathrm{O}_{2}$ exposure of $30 \mathrm{~L}$ for $1.0 \mathrm{ML}$ (upper plot) and $0.5 \mathrm{ML}$ (lower plot) of atomic oxygen on $\mathrm{Au}(111)$.

We estimated the reaction probability of carbonate formation assuming a statistical distribution ${ }^{7}$ in the decomposition of the surface-bound carbonate ${ }^{16} \mathrm{OC}^{18} \mathrm{O}_{2}$ and obtained values of $\sim 10^{-3}-10^{-4}$ (uncertainties of $\pm 50 \%$ ). These small values are likely part of the reason why an earlier study on $\mathrm{Au}(111)^{6}$ reported undetectable surface carbonate formation. An Arrhenius plot of the reaction probability for two oxygen coverages $(0.5$ and $1.0 \mathrm{ML})$ is shown in Figure 3 . The inverse relationship between reaction probability and temperature, with negative apparent activation energy $E_{\mathrm{a}}=-0.15 \pm 0.08 \mathrm{eV}$, is suggestive of a competition between carbonate formation and $\mathrm{C}^{18} \mathrm{O}_{2}$ desorption on the $\mathrm{O} / \mathrm{Au}(111)$ surface.

Compared to $\mathrm{Au}(111)$, the carbonate formation reaction on $\mathrm{Ag}(110)$ is very facile. ${ }^{10}$ This difference is not currently understood but could be related to surface structure or other factors (likely not entirely due to the calculated energetics described below). Using DFT we have calculated the difference in energetics for $\mathrm{CO}_{3}$ formation on $\mathrm{Au}(111), \mathrm{Au}(110), \mathrm{Ag}(111)$, and $\mathrm{Ag}(110)$. The metal surfaces were modeled with 4 (for 111) and 6 (for 110) layers, allowing the top two layers to relax. A vacuum gap of $10 \AA$ separated the slabs. A plane wave basis set with a $274 \mathrm{eV}$ cutoff was found to be sufficient for the PAW-based pseudopotentials, ${ }^{20}$ with a $4 \times 4 \times 1$ Monkhost-Pack k-point sampling of the Brillouin zone. All calculations were based upon the PW91 GGA functional. $^{21}$

Figure 4 shows calculated reaction paths for $\mathrm{CO}_{3}$ formation on the metal surfaces. The initial point on each path corresponds to the binding of a single $\mathrm{O}$ atom at the most stable site on the surface, with the zero of energy taken with respect to gas-phase $\mathrm{CO}_{2}$ and $1 /{ }_{2} \mathrm{O}_{2}$. $\mathrm{CO}_{2}$ physisorbs to $\mathrm{O}_{\mathrm{a}}$ and the two can react to form $\mathrm{CO}_{3}$. The formation of $\mathrm{CO}_{3}$ on $\mathrm{Ag}(110)$ was found to be spontaneous, and it occurs with only a very small barrier of $0.04 \mathrm{eV}$ on $\mathrm{Ag}(111)$. For $\mathrm{Au}$, however, there is a significant barrier to $\mathrm{CO}_{3}$ formation, particularly on the (111) surface. Our calculations show that $\mathrm{CO}_{3}$ is bound much more strongly to $\mathrm{Ag}$ than to $\mathrm{Au}$, consistent with our experimental results on $\mathrm{Au}(111)$ in which $\mathrm{CO}_{3}$ decomposition and $\mathrm{CO}_{2}$ desorption appear to occur in an overlapping temperature range $(90-120 \mathrm{~K})$ while on $\mathrm{Ag}(110)$, the carbonate decomposes near $485 \mathrm{~K}$ and $\mathrm{CO}_{2}$ desorbs below $160 \mathrm{~K}$.

Our DFT calculations are consistent with the observed low reaction probability on $\mathrm{Au}(111)$ since $\mathrm{CO}_{3}$ formation is activated as compared to $\mathrm{CO}_{2}$ desorption. They do not explain the apparent negative activation energy; additional calculations including surface reconstructions may be necessary.

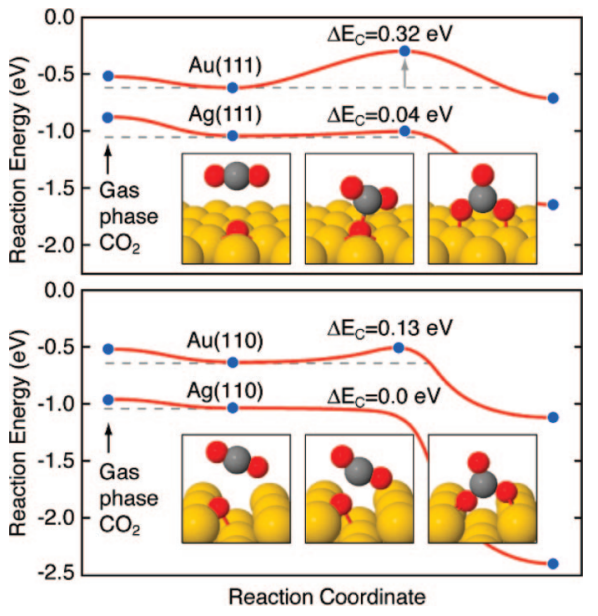

Figure 4. DFT calculations of carbonate formation on $\mathrm{Au}$ and $\mathrm{Ag}$ (111, upper plot) and (110, lower plot) surfaces. Energy barriers, $\Delta E_{\mathrm{c}}$, are labeled for each reaction pathway.

In summary, we have shown evidence for carbonate formation and reaction on atomic oxygen precovered $\mathrm{Au}(111)$. Oxygen mixing was observed when ${ }^{16} \mathrm{O}_{\mathrm{a}}$ precovered $\mathrm{Au}(111)$ was exposed to isotopically labeled $\mathrm{CO}_{2}\left(\mathrm{C}^{18} \mathrm{O}_{2}\right)$ at surface temperatures ranging from $77-400 \mathrm{~K}$ and initial oxygen coverages ranging from 0.18-2.1 ML. Subsequent desorption of isotopically mixed oxygen $\left({ }^{16} \mathrm{O}^{18} \mathrm{O}\right.$, mass 34$)$ is observed as a byproduct of carbonate formation and decomposition on the surface. Carbonate formation occurs with a very small reaction probability (ca. $10^{-3}-10^{-4}$ ) and is most favorable at low surface temperatures.

Acknowledgment. We acknowledge the Department of Energy (DE-FG02-04ER15587), Welch Foundation (F-1436; F-1601), National Science Foundation (CTS-0553243; CHE-0645497) and the donors of the Petroleum Research Fund, administered by the American Chemical Society, for their support.

\section{References}

(1) Date, M.; Haruta, M. J. Catal. 2001, 201, 221.

(2) Daté, M.; Okumura, M.; Tsubota, S.; Haruta, M. Angew. Chem., Int. Ed. 2004, 43, 2129

(3) Hakkinen, H.; Landman, U. J. Am. Chem. Soc. 2001, 123, 9704.

(4) Konova, P.; Naydenov, A.; Venkov, C.; Mehandjiev, D.; Andreeva, D.; Tabakova, T. J. Mol. Catal. A 2004, 213, 235.

(5) Outka, D. A.; Madix, R. J. Surf. Sci. 1987, 179, 351.

(6) Lazaga, M. A.; Wickham, D. T.; Parker, D. H.; Kastanas, G. N.; Koel, B. E. ACS Symp. Ser. 1993, 523, 90.

(7) Barteau, M. A.; Madix, R. J. J. Chem. Phys. 1981, 74, 4144.

(8) Bowker, M.; Barteau, M. A.; Madix, R. J. Surf. Sci. 1980, 92, 528.

(9) Campbell, C. T.; Paffett, M. T. Surf. Sci. 1984, 143, 517.

(10) Guo, X. C.; Madix, R. J. J. Phys. Chem. B 2001, 105, 3878.

(11) Behm, R. J.; Brundle, C. R. Surf. Sci. 1991, 255, 327.

(12) Felter, T. E.; Weinberg, W. H.; Lastushkina, G. Y.; Boronin, A. I.; Zhdan, P. A.; Boreskov, G. K.; Hrbek, J. Surf. Sci. 1982, 118, 369.

(13) Wang, Y.; Kovacik, R.; Meyer, B.; Kotsis, K.; Stodt, D.; Staemmler, V.; Qiu, H.; Traeger, F.; Langenberg, D.; Muhler, M.; Woll, C. Angew. Chem., Int. Ed. 2007, 46, 5624.

(14) Ojifinni, R. A.; Froemming, N. S.; Gong, J. L.; Pan, M.; Kim, T. S.; White, J. M.; Henkelman, G.; Mullins, C. B. J. Am. Chem. Soc. 2008, $130,6801$.

(15) Stiehl, J. D.; Kim, T. S.; McClure, S. M.; Mullins, C. B. J. Am. Chem. Soc. 2004, 126, 13574.

(16) Stiehl, J. D.; Kim, T. S.; McClure, S. M.; Mullins, C. B. J. Am. Chem. Soc. 2004, 126, 1606.

(17) Kim, T. S.; Gong, J.; Ojifinni, R. A.; White, J. M.; Mullins, C. B. J. Am. Chem. Soc. 2006, 128, 6282

(18) Gong, J.; Ojifinni, R. A.; Kim, T. S.; White, J. M.; Mullins, C. B. J. Am. Chem. Soc. 2006, 128, 9012.

(19) Wheeler, M. C.; Seets, D. C.; Mullins, C. B. J. Chem. Phys. 1996, 105, 1572.

(20) Kresse, G.; Joubert, D. Phys. Rev. B. 1999, 59, 1758.

(21) Perdew, J. P. In Electronic Structure of Solids' 91 ; Ziesche, P., Eschrig, H., Eds.; Akademie Verlag: Berlin, 1991; pp 11-20.. 